Marquette University

e-Publications@Marquette

10-1-2006

\title{
A New Colorimetric Assay for Methionyl Aminopeptidases: Examination of the Binding of a New Class of Pseudopeptide Analog Inhibitors
}

\author{
Sanghamitra Mitra \\ Utah State University \\ Anna M. Dygas-Holz \\ Utah State University \\ Jiri Jiracek \\ Academy of Sciences of the Czech Republic \\ Miroslava Zertova \\ Academy of Sciences of the Czech Republic \\ Lenka Zakova \\ Academy of Sciences of the Czech Republic
}

See next page for additional authors

Follow this and additional works at: https://epublications.marquette.edu/chem_fac

Part of the Chemistry Commons

\section{Recommended Citation}

Mitra, Sanghamitra; Dygas-Holz, Anna M.; Jiracek, Jiri; Zertova, Miroslava; Zakova, Lenka; and Holz, Richard C., "A New Colorimetric Assay for Methionyl Aminopeptidases: Examination of the Binding of a New Class of Pseudopeptide Analog Inhibitors" (2006). Chemistry Faculty Research and Publications. 334.

https://epublications.marquette.edu/chem_fac/334 


\section{Authors}

Sanghamitra Mitra, Anna M. Dygas-Holz, Jiri Jiracek, Miroslava Zertova, Lenka Zakova, and Richard C. Holz 
Marquette University

\section{e-Publications@Marquette}

\section{Chemistry Faculty Research and Publications/College of Arts and Sciences}

This paper is NOT THE PUBLISHED VERSION; but the author's final, peer-reviewed manuscript. The published version may be accessed by following the link in the citation below.

Analytical Biochemistry, Vol. 357, No. 1 (October 2006): 43-49. DOI. This article is (C) Elsevier and permission has been granted for this version to appear in e-Publications@Marquette. Elsevier does not grant permission for this article to be further copied/distributed or hosted elsewhere without the express permission from Elsevier.

\section{A new colorimetric assay for methionyl aminopeptidases: Examination of the binding of a new class of pseudopeptide analog inhibitors}

Sanghamitra Mitra

Department of Chemistry and Biochemistry, Utah State University, Logan, UT 84322, USA

Anna M. Dygas-Holz

Department of Chemistry and Biochemistry, Utah State University, Logan, UT 84322, USA

Jiri Jiracek

Department of Biological Chemistry, Institute of Organic Chemistry and Biochemistry, Academy of Sciences of the Czech Republic, 16610 Praha 6, Czech Republic

Miroslava Zertova

Department of Biological Chemistry, Institute of Organic Chemistry and Biochemistry, Academy of Sciences of the Czech Republic, 16610 Praha 6, Czech Republic

Lenka Zakova 
Department of Biological Chemistry, Institute of Organic Chemistry and Biochemistry, Academy of Sciences of the Czech Republic, 16610 Praha 6, Czech Republic

Richard C. Holz

Department of Chemistry, Marquette University, Milwaukee, WI 532233

Department of Chemistry and Biochemistry, Utah State University, Logan, UT 84322, USA

Department of Chemistry, Loyola University-Chicago, Chicago, IL 60626, USA

\begin{abstract}
A direct and convenient spectrophotometric assay has been developed for methionine aminopeptidases (MetAPs). The method employs the hydrolysis of a substrate that is a methionyl analogue of $p$-nitroaniline (IMet- $p$-NA), which releases the chromogenic product $p$-nitroaniline. This chromogenic product can be monitored continuously using a UV-Vis spectrophotometer set at $405 \mathrm{~nm}$. The assay was tested with the type I MetAP from Escherichia coli (EcMetAP-I) and the type II MetAP from Pyrococcus furiosus (PfMetAP-II). Using I-Met- $p$-NA, the kinetic constants $k_{\text {cat }}$ and $K_{\mathrm{m}}$ were determined for EcMetAP-I and PfMetAP-II and were compared with those obtained with a "standard" high-performance liquid chromatography (HPLC) discontinuous assay. The assay has also been used to determine the temperature dependence of the kinetic constant $k_{\text {cat }}$ for PfMetAP-II as well as to screen two novel pseudopeptide inhibitors of MetAPs. The results demonstrate that I-Met- $p$-NA provides a fast, convenient, and effective substrate for both type I and type II MetAPs and that this substrate can be used to quickly screen inhibitors of MetAPs.
\end{abstract}

\title{
Keywords
}

Methionine aminopeptidases, Spectrophotometric assay, Enzyme inhibition

\section{Introduction}

Angiogenesis is a crucial step in the pathogenesis of numerous human diseases, including diabetic retinopathy, rheumatoid arthritis, and cancer [1], [2], [3], [4]. It has been shown that malignant tumors cannot grow and metastasize without the formation of new blood vessels that provide oxygen, nutrients, and various growth factors. In addition, tumors use newly formed blood vessels to disseminate invasive tumor cells. Thus, the inhibition of angiogenesis is a promising strategy for the treatment of cancer. TNP-470, a synthetic derivative of a fungal metabolite fumagillin, was one of the first antiangiogenesis agents to enter clinical trials [5]. The activity of this sesquiterpene epoxide-containing molecule was evaluated for the treatment of a variety of cancers such as Kaposi's sarcoma, cervical cancer, brain cancer, and renal cell carcinoma [6]. Based on fumagillin affinity chromatography and mass spectrometry, methionine aminopeptidases (MetAPs) $\underline{1}$ were identified as the molecular targets of fumagillin and TNP-470 [7], [8]. Furthermore, in vivo studies showed that one of the observed effects of inhibiting MetAPs by antiangiogenesis agents is the failure to expose glycine residues at the $N$ termini of certain signaling proteins involved in cell cycle regulation, which prevents myristolyation [9]. Therefore, MetAPs are an extremely promising target for the design of a novel class of antiangiogenesis drugs, some of which currently are under clinical investigation [5], [10], [11], [12], [13], [14], [15], [16], [17], [18].

MetAPs are capable of the hydrolytic removal of an $\mathrm{N}$-terminal methionine residue from nascent polypeptide chains [19], [20], [21], [22]. Because the biosynthesis of all eukaryotic proteins present in the cytosol starts with the initiator methionine, MetAPs play a central role in protein synthesis [23]. The structure of mature $N$ termini plays important roles in $\mathrm{N}$-directed degradation pathways and in targeting cellular membranes [24], [25]. Therefore, MetAPs are one of the key cellular enzymes involved in protein maturation. MetAPs are organized into two classes (types I and II) based on the absence or presence of an extra 62-amino acid sequence (of unknown function) inserted near the catalytic domain of type II enzymes. The type I MetAPs from Escherichia coli (EcMetAP-I), Staphylococcus aureus (SaMetAP-I), Thermotoga maritime (TmMetAP-I), and Homo sapiens 
(HsMetAP-I), and the type II MetAPs from Homo sapiens (HsMetAP-II) and Pyrococcus furiosus (PfMetAP-II), have been characterized crystallographically [26], [27], [28], [29], [30], [31], [32]. All six display a novel "pita bread" fold with an internal pseudo-twofold symmetry that structurally relates the first and second halves of the polypeptide chain to each other. Each half contains an antiparallel $\beta$-pleated sheet flanked by two helical segments and a C-terminal loop. Both domains contribute conserved residues to the metallo-active site. In all five structures, a bis( $\mu$-carboxylato)( $\mu$-aquo/hydroxo)dicobalt(II) core is observed with an additional carboxylate residue at each metal site and a single histidine bound to Co1.

A major issue that has plagued research efforts on MetAPs is the lack of a fast and simple spectrophotometric assay. To date, the most widely used assay involves determining the amount of product (I-Met) formed by highperformance liquid chromatography (HPLC) [33], [34], [35]. Even though this assay is very accurate, it is very time-consuming and expensive to run. To develop a simple, inexpensive, and fast continuous assay for MetAPs, here we report the monitoring of amide bond cleavage by both type I and type II MetAPs using a methionyl analogue of $p$-nitroaniline (I-Met-p-NA). Proof of concept that this assay is functional is shown by comparison of kinetic data obtained with I-Met- $p$-NA with the peptide substrate MGMM using a discontinuous HPLC assay. We also use I-Met- $p$-NA to investigate the potency of two new MetAP inhibitors.

\section{Materials and methods}

\section{Protein expression, purification, and metal activation}

EcMetAP-I and PfMetAP-II were purified as described previously [12], [33]. Purified EcMetAP-I and PfMetAP-II exhibited single bands on sodium dodecyl sulfate-polyacrylamide gel electrophoresis (SDS-PAGE) at $M_{\mathrm{r}} 29,630$ and $M_{\mathrm{r}} 32,850$, respectively. Protein concentrations for EcMetAP-I and PfMetAP-II were estimated from the absorbance at $280 \mathrm{~nm}$ using extinction coefficients of 16,445 and $21,650 \mathrm{M}^{-1} \mathrm{~cm}^{-1}$, respectively [12], [33], [35]. Apo-EcMetAP-I was washed free of methionine using Chelex-100-treated methionine-free buffer ( $25 \mathrm{mM}$ Hepes [pH 7.5] and $150 \mathrm{mM} \mathrm{KCl}$ ) and was concentrated by microfiltration using a Centicon-10 (Amicon, Beverly, MA, USA) prior to all kinetic assays. Individual aliquots of apo-EcMetAP-I were routinely stored at $-80^{\circ} \mathrm{C}$ or in liquid nitrogen until needed. Apo-EcMetAP-I and apo-PfMetAP-II samples used in catalytic measurements were made rigorously anaerobic prior to incubation with 3 eq of $\mathrm{Co}$ (II) $\left(\mathrm{CoCl}_{2} \geqslant 99.999 \%\right.$, Strem Chemicals, Newburyport, MA, USA) for approximately $30 \mathrm{~min}$ at $20-25^{\circ} \mathrm{C}$. Co(II)-containing samples were handled throughout in an anaerobic glove box $\left(\mathrm{Ar} / 5 \% \mathrm{H}_{2}, \leqslant 1 \mathrm{ppm} \mathrm{O}_{2}\right.$, Coy Laboratories, Ann Arbor, MI, USA) until frozen. Electronic absorption measurements were performed on a Shimadzu UV-3101PC spectrophotometer.

\section{Discontinuous enzymatic assay of MetAPs}

All enzymatic assays were performed under strict anaerobic conditions in an inert atmosphere glove box (Coy Laboratories) with a dry bath incubator to maintain the temperature. Catalytic activities were determined with an error of $\pm 5 \%$ using the substrate MGMM in $25 \mathrm{mM}$ Chelex-100-treated methionine-free Hepes buffer ( $\mathrm{pH} 7.5$ ) containing $150 \mathrm{mM} \mathrm{KCl}$. The amount of product (I-Met) formation was determined by HPLC (Shimadzu LC-10A class-VP5). A typical assay involved the addition of $8 \mu \mathrm{l}$ of metal-loaded WT EcMetAP-I enzyme to a 32- $\mu \mathrm{l}$ substrate-buffer mixture at $30^{\circ} \mathrm{C}$ for $1 \mathrm{~min}$. The reaction was quenched by the addition of $40 \mu \mathrm{l}$ of a $1 \%$ trifluoroacetic acid (TFA) solution. Elution of the product was monitored at $215 \mathrm{~nm}$ following separation on a C8 HPLC column (Phenomenex Luna, $5 \mu \mathrm{m}, 4.6 \times 25 \mathrm{~cm}$ ), as described previously [33], [34], [35].

\section{Synthesis of I-MetStaCys and I-MetStaVal}

I-MetStaCys and I-MetStaVal were synthesized by solid-phase synthesis on Rink Amide AM resin using an $\mathrm{N}$-Bocprotected statine derivative of I-Met, $(3 S, 4 S)$-4-tert-butoxycarbonylamino-3-hydroxy-6-methylsulfanyl-hexanoic acid, which was prepared according to Jouin and co-workers [36]. This synton (1.4 eq) was attached to resinbound Val or Cys(Trt) (1 eq) using $N, N^{\prime}$-diisopropylcarbodiimide (3 eq) and $N$-hydroxybenzotriazole (5 eq) as coupling agents in a mixture of $\mathrm{N}$-methylpyrrolidinone and dichloromethane overnight. Pseudopeptides were 
cleaved off the resin with a mixture of $97 \%$ TFA, $1 \%$ ethanedithiol, $1 \%$ trisopropylsilane, and $1 \%$ water. The inhibitors were purified using HPLC and characterized by mass spectrometry.

\section{Results and discussion}

Several discontinuous assays have been reported, with the most used ones being (i) HPLC detection of the reaction product I-Met, (ii) amino acid oxidase together with horseradish peroxidase and monitoring of the absorbance at $440 \mathrm{~nm}$ [24], [37], [38], and (iii) reaction of I-Met with a chromogenic or fluorogenic tag and analysis of the derivatives by HPLC or by capillary electrophoresis [39], [40]. Although these assays are indeed functional, several problems exist for all of them (e.g., long incubation times, time-consuming, labor-intensive, expensive, significant background noise). Recently, two complementary, continuous MetAP assays were reported [41]. In the first, a thioester substrate was used; on exposure of the free thiol group by the action of MetAP, the amount of free thiol was quantified by 5,5'-dithio-bis(2-nitrobenzoic) acid (DTNB) [41]. Although a creative approach to assay MetAPs, DTNB is known to inactivate EcMetAP-I (and likely all type I MetAPs) by modifying active site cysteine residues [42]. Alternatively, a coupled spectrophotometric assay in which the dipeptide substrate Met-Pro- $p$-NA was employed was reported [41]. In this assay, the N-terminal methionine residue was removed by MetAP, followed by cleavage of I-Pro by a prolyl aminopeptidase, releasing $p$ nitroaniline [41]. Although this assay is relatively simple to use, one major problem involves cross-reactivity of potential MetAP inhibitors when attempting to obtain $K_{\mathrm{i}}$ values. To overcome problems with the currently available assay methods for MetAPs, we have examined amide bond cleavage by both type I and type II MetAPs using a methionyl analogue of $p$-nitroaniline (I-Met-p-NA).

Recently, it was shown that HsMetAP-II could use substrates smaller than dipeptides, such as I-methionine-7amido-4-methylcoumarin (I-Met-AMC) and I-Met-p-NA, whereas EcMetAP-I was shown to hydrolyze I-Met from I-Met-AMC [43]. However, it was reported previously that yeast MetAP-I was unable to cleave I-Met- $p$-NA [44]. Even so, we hypothesized that both type I and type II MetAPs could hydrolyze I-Met- $p$-NA, contrary to previous reports [24]. Therefore, the hydrolytic activity of Co(II)-reconstituted ECMetAP-I and PfMetAP-II was examined with I-Met- $p$-NA as the substrate. A typical reaction of 1, 4, or $12 \mu \mathrm{M}$ PfMetAP-II or EcMetAP-I with I-Met-p-NA was carried out at $30^{\circ} \mathrm{C}$ in a quartz cuvette containing $25 \mathrm{mM}$ Hepes buffer at pH 7.5 with $150 \mathrm{mM} \mathrm{KCl}$ and monitoring the absorbance at $405 \mathrm{~nm}\left(\varepsilon=10,800 \mathrm{M}^{-1} \mathrm{~cm}^{-1}\right)$ for $10 \mathrm{~min}$. The rate of background hydrolysis of IMet- $p$-NA was measured by monitoring the formation of $p$-nitroaniline continuously at $405 \mathrm{~nm}$ and was subtracted. Interestingly, the absorbance at $405 \mathrm{~nm}$ in the presence of PfMetAP-II or ECMetAP-I increased linearly with time (Fig. 1), and the amount of product released was linearly dependent on the concentration of the enzyme (Fig. 2). As a control, I-Ala- $p$-nitroaniline and I-Leu- $p$-nitroaniline were examined, and (as expected) neither PfMetAP-II nor EcMetAP-I could use these substrates. These data clearly show that I-Met- $p$-NA can function as a substrate for both type I and type II MetAPs.

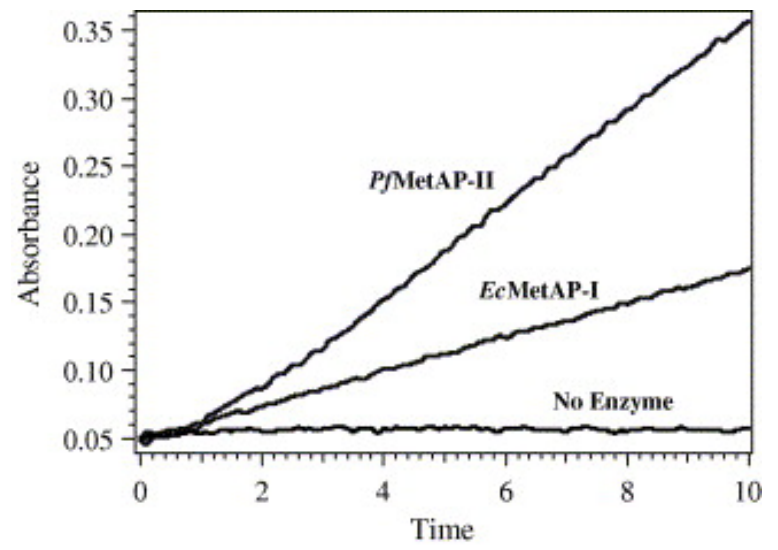

Fig. 1. Time course for the hydrolysis of I-Met-p-NA $(1 \mathrm{mM})$ by EcMetAP-I $(4 \mu \mathrm{M})$ and PfMetAP-II $(1 \mu \mathrm{M})$ in $25 \mathrm{mM}$ Hepes buffer (pH 7.5) and $150 \mathrm{mM} \mathrm{KCl}$. 


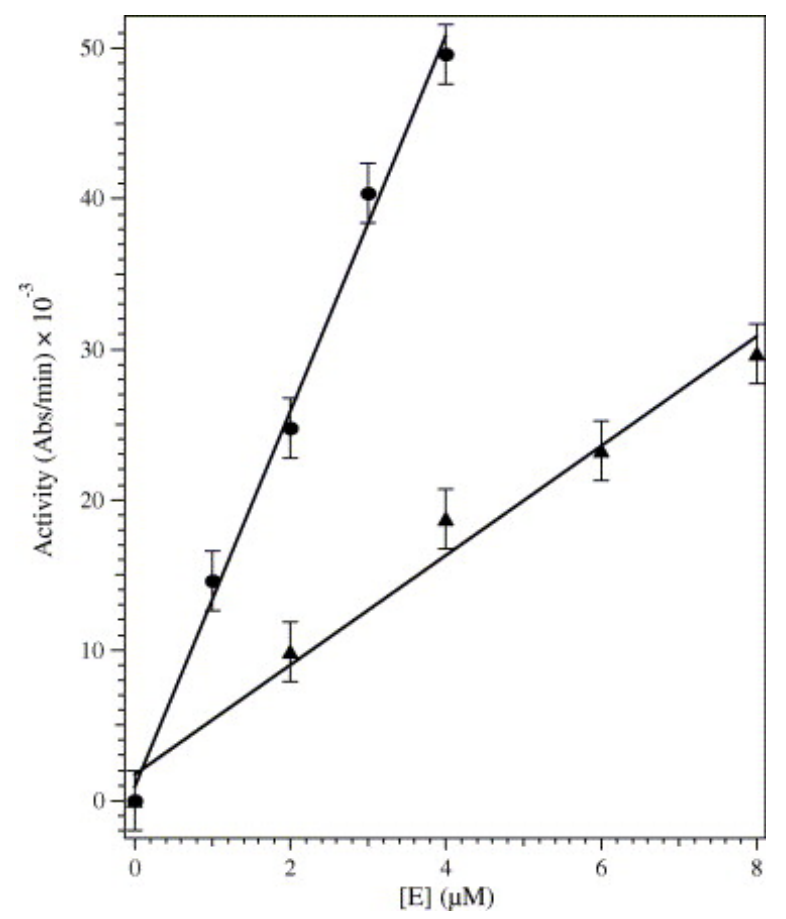

Fig. 2. Effect of EcMetAP-I (solid triangles) and PfMetAP-II (solid circles) concentration on the hydrolysis of IMet- $p$-NA (1 mM) in $25 \mathrm{mM}$ Hepes buffer (pH 7.5) and $150 \mathrm{mM} \mathrm{KCl}$.

Both PfMetAP-II and EcMetAP-I exhibited saturation kinetics when I-Met- $p$-NA was used as a substrate (Fig. 3 ). Activity assays using I-Met- $p$-NA were performed in triplicate and revealed that Co(II)-loaded PfMetAP-II is more active than Co(II)-loaded EcMetAP-I (Table 1). $K_{\mathrm{m}}$ and $k_{\text {cat }}$ values were obtained by nonlinear fitting of the data to the Michaelis-Menten equation. For PfMetAP-II, the $k_{\text {cat }}$ value observed for I-Met- $p$-NA at $30{ }^{\circ} \mathrm{C}$ was $0.057 \mathrm{~s}^{-1}$ $\left(K_{\mathrm{m}}=0.59 \mathrm{mM}\right)$, providing a catalytic efficiency of $97.0 \mathrm{M}^{-1} \mathrm{~s}^{-1}$, whereas EcMetAP-I exhibited a $k_{\text {cat }}$ value of $0.006 \mathrm{~s}^{-1}\left(K_{\mathrm{m}}=0.44 \mathrm{mM}\right)$, providing a catalytic efficiency of $13.7 \mathrm{M}^{-1} \mathrm{~s}^{-1}$. For comparison purposes, the kinetic parameters for Co(II)-loaded EcMetAP-I and Co(II)-loaded PfMetAP-II were determined using MGMM as the substrate (Table 1) [35]. Activity assays were performed in triplicate for 8-15 concentrations of MGMM (0$12 \mathrm{mM}$ ), and the product (I-Met) was quantified by a discontinuous HPLC assay [35]. $K_{\mathrm{m}}$ and $k_{\text {cat }}$ values were obtained by nonlinear fitting of the data to the Michaelis-Menten equation. For PfMetAP-II, the $k_{\mathrm{cat}}$ value for MGMM at $30^{\circ} \mathrm{C}$ was $188 \mathrm{~s}^{-1}\left(K_{\mathrm{m}}=5.1 \mathrm{mM}\right)$, providing a catalytic efficiency of $37,000 \mathrm{M}^{-1} \mathrm{~s}^{-1}$, whereas $E c M e t A P-I$ exhibited a $k_{\text {cat }}$ value of $18.3 \mathrm{~s}^{-1}\left(K_{\mathrm{m}}=3.0 \mathrm{mM}\right)$, providing a catalytic efficiency of $6100 \mathrm{M}^{-1} \mathrm{~s}^{-1}$. Therefore, both EcMetAP-I and PfMetAP-II are much poorer catalysts for the cleavage of I-Met from I-Met- $p$-NA by approximately 440 and 380 times, respectively. Even though the catalytic efficiencies were small, this assay was found to be very sensitive and reproducible because I-Met- $p$-NA binds more tightly to both type I and type II MetAPs and the highly chromogenic product that can be monitored continuously at $405 \mathrm{~nm}$. Therefore, the simplicity of a direct spectrophotometric assay suggests that I-Met-p-NA is the substrate of choice for analyzing MetAP activity. 


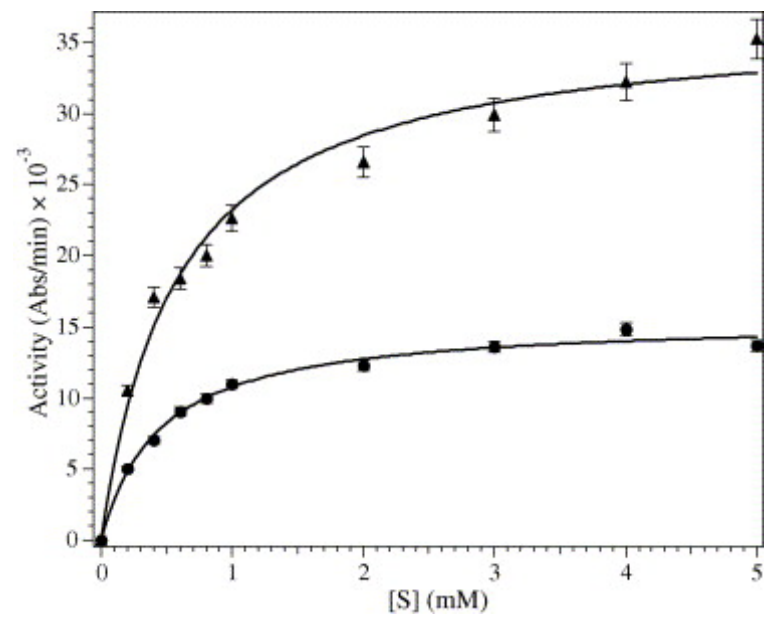

Fig. 3. Michaelis-Menten plot for the hydrolysis of I-Met- $p$-NA by EcMetAP-I (solid circles) and PfMetAP-II (solid triangles) in $25 \mathrm{mM}$ Hepes buffer (pH 7.5) and $150 \mathrm{mM} \mathrm{KCl}$.

Table 1. Kinetic constants for Co(II)-loaded EcMetAP-I and PfMetAP-II using MGMM and I-Met-p-NA in 25 mM Hepes buffer at $30^{\circ} \mathrm{C}(\mathrm{pH} \mathrm{7.5)}$ with $150 \mathrm{mM} \mathrm{KCl}$

\begin{tabular}{|l|l|l|l|}
\hline & Kinetic constants & I-Met-p-NA & MGMM \\
\hline ECMetAP-I & $K_{\mathrm{m}}(\mathrm{mM})$ & $0.44 \pm 0.03$ & $3.0 \pm 0.1$ \\
\hline & $k_{\text {cat }}\left(\mathrm{s}^{-1}\right)$ & 0.006 & 18.3 \\
\hline & $k_{\text {cat }} / K_{\mathrm{m}}\left(\mathrm{M}^{-1} \mathrm{~s}^{-1}\right)$ & 13.7 & 6100 \\
\hline & $\mathrm{SA}(\mathrm{U} / \mathrm{mg})$ & $1.3 \times 10^{-2}$ & 36.0 \\
\hline PfMetAP-II & $K_{\mathrm{m}}(\mathrm{mM})$ & $0.59 \pm 0.07$ & $5.1 \pm 0.3$ \\
\hline & $k_{\text {cat }}\left(\mathrm{s}^{-1}\right)$ & 0.057 & 188 \\
\hline & $k_{\text {cat }} / K_{\mathrm{m}}\left(\mathrm{M}^{-1} \mathrm{~s}^{-1}\right)$ & 97.0 & 37,000 \\
\hline & $\mathrm{SA}(\mathrm{U} / \mathrm{mg})$ & $1.1 \times 10^{-1}$ & 340 \\
\hline
\end{tabular}

It was reported previously [35] that the optimal activity for PfMetAP-II toward MGMM occurred at $85^{\circ} \mathrm{C}$ in $25 \mathrm{mM}$ Hepes ( $\mathrm{pH} 7.5)$ and $150 \mathrm{mM} \mathrm{KCl}$ buffer. Therefore, the hydrolysis of I-Met-p-NA was examined in triplicate between 25 and $90^{\circ} \mathrm{C}$ at a substrate concentration of $5 \mathrm{mM}$. The calculated specific activity values were plotted as a function of temperature between 25 and $90^{\circ} \mathrm{C}$. The specific activity values for I-Met- $p$-NA hydrolysis catalyzed by Co(II)-loaded PfMetAP-II were found to increase with increasing temperature. In a simple rapid equilibrium, $V_{\max } /[\mathrm{E}]=k_{\mathrm{p}}$, the first-order rate constant. Because the enzyme concentration was not altered over the course of the experiment, an Arrhenius plot could be constructed by plotting $\ln \left(k_{\text {cat }}\right)$ versus $1 / T$ ( $\underline{\text { Fig. } 4}$ ). The linearity of the Arrhenius plot indicates that the rate-limiting step does not change as a function of temperature [45]. From the slope of the line, the activation energy, $E_{\mathrm{a}}$, for temperatures between 296 and $358 \mathrm{~K}$ was calculated to be $54 \mathrm{~kJ} / \mathrm{mol}$ for Co(II)-loaded PfMetAP-II but was $13.3 \mathrm{~kJ} / \mathrm{mol}$ using MGMM as the substrate [35]. These data compare well with the $E_{\mathrm{a}}$ values reported for the aminopeptidase from Aeromonas proteolytica $(36.5 \mathrm{~kJ} / \mathrm{mol})$, which has a similar activation energy to pronase and both thermolysin and carboxypeptidase A [46], [47], [48]. The fact that the activation energy is approximately fourfold higher for the hydrolysis of I-Met-pNA by Co(II)-loaded PfMetAP-II is constant with the observed decrease in $k_{\text {cat }}$ when I-Met- $p$-NA is used as a substrate. 


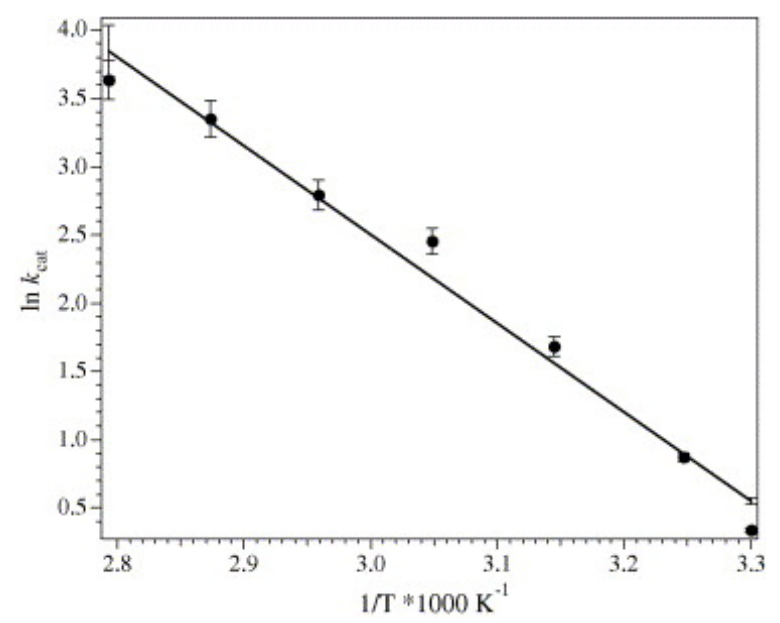

Fig. 4. Arrhenius plot of $\ln \left(k_{\text {cat }}\right)$ versus $1 / T$ for Co(II)-loaded PfMetAP-II using I-Met- $p$-NA as the substrate in $25 \mathrm{mM}$ Hepes buffer (pH 7.5) and $150 \mathrm{mM} \mathrm{KCl}$.

Because the slope of an Arrhenius plot is equal to $-E_{\mathrm{a} 1} / R$, where $R=8.3145 \mathrm{JK}^{-1} \mathrm{~mol}^{-1}$, thermodynamic parameters for the hydrolysis of I-Met- $p$-NA by Co(II)-loaded PfMetAP-II were calculated by the following relations: $\Delta G^{\neq}=-R T \ln \left(k_{\mathrm{cat}} h / k_{\mathrm{B}} T\right), \Delta H^{\neq}=E_{\mathrm{a}}-R T, \Delta S^{\neq}=\left(\Delta H^{\neq}-\Delta G^{\neq}\right) / T$, where $R, h$, and $k_{\mathrm{B}}$ are the gas, Boltzmann, and Planck constants, respectively (Table 2 ). The enthalpy of activation calculated over the temperature range $25-90^{\circ} \mathrm{C}$ is $47.5 \mathrm{~kJ} / \mathrm{mol}$ for Co(II)-loaded PfMetAP-II, whereas the entropy of activation was found to be $-79.9 \mathrm{~J} / \mathrm{mol} / \mathrm{K}$ at $25^{\circ} \mathrm{C}$. The positive enthalpy, which is approximately four times larger than the enthalpy observed using MGMM as the substrate, is indicative of a conformation change on substrate binding likely due to the energy of bond formation and breaking during nucleophilic attack on the scissile carbonyl carbon of the substrate [35]. On the other hand, the large negative entropy value, which is similar in magnitude to the enthalpy observed using MGMM as the substrate $(-119.7 \mathrm{~J} / \mathrm{mol} / \mathrm{K})$, suggests that some molecular motions are lost on $\mathrm{ES}^{\ddagger}$ complex formation, possibly due to hydrogen bond formation between catalytically important amino acids and the substrate [35]. All of these factors contribute to the large positive free energy of activation $(71.3 \mathrm{~kJ} / \mathrm{mol})$, which is nearly double the value observed using MGMM as the substrate [35].

Table 2. Thermodynamic parameters for hydrolysis of I-Met- $p$-NA by Co(II)-loaded PfMetAP-II in 25 mM Hepes buffer (pH 7.5) and $150 \mathrm{mM} \mathrm{KCl}$

\begin{tabular}{|l|l|l|l|l|}
\hline & $\boldsymbol{E}_{\mathrm{a}}(\mathbf{k J} / \mathbf{m o l})$ & $\boldsymbol{\Delta} \boldsymbol{H}^{\mathbf{*}}(\mathbf{k J} / \mathbf{m o l})$ & $\boldsymbol{\Delta} \boldsymbol{G}^{\neq}(\mathbf{k J} / \mathbf{m o l})$ & $\boldsymbol{\Delta} \boldsymbol{S}^{ \pm}(\mathbf{J} / \mathbf{m o l} / \mathbf{K})$ \\
\hline I-Met-p-NA & 54.0 & 47.5 & 71.3 & -79.9 \\
\hline
\end{tabular}

Finally, we have designed and synthesized several pseudopeptides that have nonhydrolyzable moiety that mimics the transition state of the substrate in the active site of MetAPs that represent a new class of MetAP inhibitors. These molecules are based on a statine derivative of I-Met with a Cys (I-MetStaCys, 1) or a Val (IMetStaVal, 2) attached to the $C$ terminus of the statine synthon (ig. 5 ). Both $\mathbf{1}$ and $\mathbf{2}$ were tested for their ability to inhibit Co(II)-loaded EcMetAP-I and PfMetAP-II (Fig. 5) using I-Met-p-NA as the substrate. The reaction rates of Co(II)-loaded ECMetAP-I and PfMetAP-II in the presence of 0-1 mM of 1 or $\mathbf{2}$ were monitored continuously at $405 \mathrm{~nm}$, and the initial rates were calculated. The $I_{50}$ values for 1 and $\mathbf{2}$ were obtained from plots of the ratio of the initial rates with and without the inhibitor against inhibitor concentrations (Fig. 6 ). The $I C_{50}$ values for 1 inhibiting Co(II)-loaded EcMetAP-I and PfMetAP-II were found to be $2.5 \pm 0.1$ and $1.7 \pm 0.2 \mu \mathrm{M}$, respectively, whereas 2 exhibited IC $C_{50}$ values of $4.3 \pm 0.4$ and $2.0 \pm 0.1 \mu \mathrm{M}$ for Co(II)-loaded EcMetAP-I and PfMetAP-II, respectively. The $I_{50}$ values observed for $\mathbf{1}$ and $\mathbf{2}$ binding to PfMetAP-II using I-Met- $p$-NA as the substrate compare well with $I_{50}$ values $(1.5 \pm 0.1$ and $2.0 \pm 0.1 \mu \mathrm{M}$, respectively) obtained for the $\mathrm{Mn}$ (II)-loaded PfMetAPII using the discontinuous HPLC assay that uses MGMM as the substrate. These data indicate that using I-Met-pNA as a substrate for type I and type II MetAPs provides a fast, convenient, and direct spectrophotometric assay 
with which to screen potential inhibitors of MetAPs. Moreover, these data indicate that the I-MetStaCys and IMetStaVal are good inhibitors of both type I and type II MetAPs, suggesting that the I-MetSta scaffolding provides an excellent base for the synthesis of new MetAP inhibitors.<smiles>CSCC[C@H](N)[C@@H](O)CC(=O)N[C@@H](CS)C(N)=O</smiles><smiles>CSCC[C@H](N)[C@@H](O)CC(=O)N[C@H](C(N)=O)C(C)C</smiles>

Fig. 5. Chemical structures of the I-MetSta $X(X=C y s, 1$, and Val, 2) pseudopeptide MetAP inhibitors.

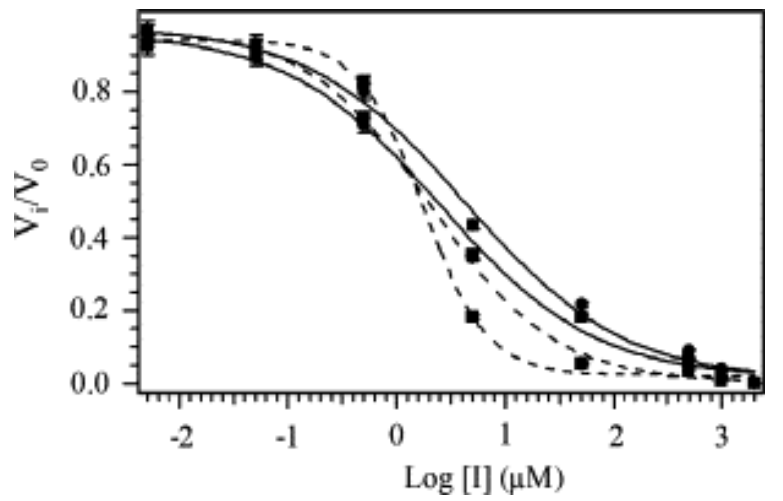

Fig. 6. Dose-dependent curves for the inhibition of EcMetAP-I (solid lines) and PfMetAP-II (dashed lines) by 1 (circles) and 2 (squares) at $30^{\circ} \mathrm{C}$ in $25 \mathrm{mM} \mathrm{Hepes} \mathrm{buffer} \mathrm{(pH} \mathrm{7.5)} \mathrm{and} 150 \mathrm{mM} \mathrm{KCl}$.

\section{Acknowledgments}

This work was supported by the National Science Foundation (CHE-0549221 to R.C.H.), by the Grant Agency of the Academy of Sciences of the Czech Republic (203/06/1405 to J.J.), and by the Research Project of the Academy of Sciences of the Czech Republic (Z40550506 to J.J.). 


\section{References}

[1] J. Folkman What is the evidence that tumors are angiogenesis dependent? J. Natl. Cancer Inst., 82 (1990), pp. 4-6

[2] J. Folkman Angiogenesis in cancer, vascular, rheumatoid, and other disease Nat. Med., 1 (1995), pp. 27-31

[3] J. Folkman Tumor angiogenesis Adv. Cancer Res., 43 (1985), pp. 175-203

[4] S.G. Bernier, D.D. Lazarus, E. Clark, B. Doyle, M.T. Labenski, C.D. Thompson, W.F. Westlin, G. Hanni A methionine aminopeptidase-2 inhibitor, PPI-2458, for the treatment of rheumatoid arthritis Proc. Natl. Acad. Sci. USA, 101 (2004), pp. 10768-10773

[5] E.A. Kruger, W.D. Figg TNP-470: an angiogenesis inhibitor in clinical development for cancer Expert Opin. Investig. Drugs, 9 (2000), pp. 1383-1396

[6] P. Selvakumar, A. Lakshmikuttyamma, R. Kanthan, S.C. Kanthan, J.R. Dimmock, R.K. Sharma High expression of methionine aminopeptidase 2 in human colorectal adenocarcinomas Clin. Cancer Res., 10 (2004), pp. 2771-2775

[7] R. Bradshaw, E. Yi Methionine aminopeptidases and angiogenesis Essays Biol. Med., 38 (2002), pp. 65-78

[8] N. Sin, L. Meng, M.Q.W. Wang, J.J. Wen, W.G. Bornmann, C.M. Crews The anti-angiogenic agent fumagillin covalently binds and inhibits the methionine aminopeptidase, MetAP-2 Proc. Natl. Acad. Sci. USA, 94 (1997), pp. 6099-6103

[9] P. Selvakumar, A. Lakshmikuttyamma, Z. Lawman, K. Bonham, J.R. Dimmock, R.K. Sharma Expression of methionine aminopeptidase $\mathbf{2 , N}$-myristoyltransferase, and $\mathbf{N}$-myristoyltransferase inhibitor protein 71 in HT29 Biochem. Biophys. Res. Commun., 322 (2004), pp. 1012-1017

[10] E.C. Griffith, Z. Su, B.E. Turk, S. Chen, Y-H. Chang, Z. Wu, K. Biemann, J.O. Liu Methionine aminopeptidase (type 2) is the common target for angiogenesis inhibitors AGM-1470 and ovalicin Chem. Biol., 4 (1997), pp. 461-471

[11] E.C. Griffith, Z. Su, S. Niwayama, C.A. Ramsay, Y-H. Chang, J.O. Liu Molecular recognition of angiogenesis inhibitors fumagillin and ovalicin by methionine aminopeptidase 2 Proc. Natl. Acad. Sci. USA, 95 (1998), pp. 15183-15188

[12] W.T. Lowther, D.A. McMillen, A.M. Orville, B.W. Matthews The anti-angiogenic agent fumagillin covalently modifies a conserved active site histidine in the Escherichia coli methionine aminopeptidase Proc. Natl. Acad. Sci. USA, 95 (1998), pp. 12153-12157

[13] S. Liu, J. Widom, C.W. Kemp, C.M. Crews, J. Clardy Structure of human methionine aminopeptidase-2 complexes with fumagillin Science, 282 (1998), pp. 1324-1327

[14] R.A. Bradshaw, E. Yi Methionine aminopeptidases and angiogenesis Essays Biochem., 38 (2002), pp. 65-78

[15] J. Taunton How to starve a tumor Chem. Biol., 4 (1997), pp. 493-496

[16] W.D. Figg, E.A. Kruger, D.K. Price, S. Kim, W.D. Dahut Inhibition of angiogenesis: treatment options for patients with metastatic prostate cancer Invest. New Drugs, 20 (2002), pp. 183-194

[17] Y. Zhang, E.C. Griffith, J. Sage, T. Jacks, J.O. Liu Cell cycle inhibition by the anti-angiogenic agent TNP-470 is mediated by $\mathrm{p} 53$ and p21WAF1/CIP1 Proc. Natl. Acad. Sci. USA, 97 (2000), pp. 6427-6432

[18] S. Koyanagi, H. Nakagawa, Y. Kuramoto, S. Ohdo, S. Soeda, H. Shimeno Optimizing the dosing schedule of TNP-470 [O-(chloroacetyl-carbamoyl)fumagillol] enhances its antitumor and antiangiogenic efficacies J. Pharmacol. Exp. Ther., 304 (2003), pp. 669-674

[19] R.A. Bradshaw Protein translocation and turnover in eukaryotic cells Trends Biochem. Sci., 14 (1989), pp. 276-279

[20] T. Meinnel, Y. Mechulam, S. BlanquetMethionine as translation start signal: a review of the enzymes of the pathway in Escherichia coli Biochimie, 75 (1993), pp. 1061-1075

[21] R.A. Bradshaw, W.W. Brickey, K.W. Walker $\mathbf{N}$-terminal processing: the methionine aminopeptidase and $\boldsymbol{N}^{\mathrm{a}}$ acetyl transferase families Trends Biochem. Sci., 23 (1998), pp. 263-267

[22] S.M. Arfin, R.A. Bradshaw Cotranslational processing and protein turnover in eukaryotic cells Biochemistry, 27 (1988), pp. 7979-7984 
[23] P.-H. Hirel, J.-M. Schmitter, P. Dessen, G. Fayat, S. Blanquet Extent of $\mathbf{N}$-terminal methionine excision from Escherichia coli proteins is governed by the side-chain length of the penultimate amino acid Proc. Natl. Acad. Sci. USA, 86 (1989), pp. 8247-8251

[24] A. Ben-Bassat, A. Bauer, S.-Y. Chang, K. Myambo, A. Boosman, S. Chang Processing of the initiation methionine from proteins: properties of the Escherichia coli methionine aminopeptidase and its gene structure J. Bacteriol., 169 (1987), pp. 751-757

[25] J.W. Tobias, T.E. Shrader, G. Rocap, A. Varshavsky The N-end rule in bacteria Science, 254 (1991), pp. 13741377

[26] A. Addlagatta, X. Hu, J.O. Liu, B.W. Matthews Structural basis for the functional differences between type I and type II human methionine aminopeptidases Biochemistry, 44 (2005), pp. 14741-14749

[27] A. Douangamath, G.E. Dale, A. D'Arcy, M. Almstetter, R. Eckl, A. Frutos-Hoener, B. Henkel, K. Illgen, S. Nerdinger, H. Schulz, A. MacSweeney, M. Thormann, A. Treml, S. Pierau, S. Wadman, C. Oefner Crystal structures of Staphylococcus aureus methionine aminopeptidase complexed with keto heterocycle and aminoketone inhibitors reveal the formation of a tetrahedral intermediate J. Med. Chem., 47 (2004), pp. 1325-1328

[28] T.H. Tahirov, H. Oki, T. Tsukihara, K. Ogasahara, K. Yutani, K. Ogata, Y. Izu, S. Tsunasawa, I. Kato Crystal structure of the methionine aminopeptidase from the hyperthermophile, Pyrococcus furiosus J. Mol. Biol., 284 (1998), pp. 101-124

[29] W.T. Lowther, A.M. Orville, D.T. Madden, S. Lim, D.H. Rich, B.W. Matthews Escherichia coli methionine aminopeptidase: implications of crystallographic analyses of the native, mutant, and inhibited enzymes for the mechanism of catalysis Biochemistry, 38 (1999), pp. 7678-7688

[30] L.S. Roderick, B.W. Matthews Structure of the cobalt-dependent methionine aminopeptidase from Escherichia coli: a new type of proteolytic enzyme Biochemistry, 32 (1993), pp. 3907-3912

[31] S. Liu, J. Widom, C.W. Kemp, C.M. Crews, J. Clardy Structure of the human methionine aminopeptidase-2 complexed with fumagillin Science, 282 (1998), pp. 1324-1327

[32] G. Spraggon, R. Schwarzenbacher, A. Kreusch, D. McMullan, L.S. Brinen, J.M. Canaves, X. Dai, A.M. Deacon, M.A. Elsliger, S. Eshagi, R. Floyd, A. Godzik, C. Grittini, S.K. Grzechnik, L. Jaroszewski, C. Karlak, H.E. Klock, E. Koesema, J.S. Kovarik, P. Kuhn, T.M. McPhillips, M.D. Miller, A. Morse, K. Moy, J. Ouyang, R. Page, K. Quijano, F. Rezezadeh, A. Robb, E. Sims, R.C. Stevens, H. van den Bedem, J. Velasquez, J. Vincent, F. von Delft, X. Wang, B. West, G. Wolf, Q. Xu, K.O. Hodgson, J. Wooley, S.A. Lesley, I.A. Wilson Crystal structure of a methionine aminopeptidase (TM1478) from Thermotoga maritima at $1.9 \AA$ resolution Proteins, 56 (2004), pp. 396-400

[33] V.M. D'souza, R.C. Holz The methionyl aminopeptidase from Escherichia coli is an iron(II) containing enzyme Biochemistry, 38 (1999), pp. 11079-11085

[34] V.M. D'souza, B. Bennett, A.J. Copik, R.C. Holz Characterization of the divalent metal binding properties of the methionyl aminopeptidase from Escherichia coli Biochemistry, 39 (2000), pp. 3817-3826

[35] L. Meng, S. Ruebush, V.M. D'souza, A.J. Copik, S. Tsunasawa, R.C. Holz Overexpression and divalent metal binding studies for the methionyl aminopeptidase from Pyrococcus furiosus Biochemistry, 41 (2002), pp. 7199-7208

[36] P. Jouin, B. Castro, D. Nisato Stereospecific synthesis synthesis of N-protected statine and its analogs via chiral tetramic acid J. Chem. Soc. Perkin Trans., 1 (1987), pp. 1177-1182

[37] J.A. Larrabee, T. Thamrong-Nawasawar, S.Y. Mon High-pressure liquid chromatographic method for the assay of methionine aminopeptidase activity: application to the study of enzymatic inactivation Anal. Biochem., 269 (1999), pp. 194-198

[38] K.W. Walker, R.A. Bradshaw Yeast methionine aminopeptidase I: alteration of substrate specificity by sitedirected mutagenesis J. Biol. Chem., 274 (1999), pp. 13403-13409

[39] R.L. Kendall, R.A. Bradshaw Isolation and characterization of the methionine aminopeptidase from porcine liver responsible for the co-translational processing of proteins J. Biol. Chem., 267 (1992), pp. 2066720673

[40] K.W. Walker, R.A. Bradshaw Protein Sci., 7 (1996), pp. 2684-2687 
[41] Y. Zhou, X.-C. Gou, T. Yi, T. Yoshimoto, D. Pei Two continuous spectrophotometric assays for methionine aminopeptidase Anal. Biochem., 280 (2000), pp. 159-165

[42] K. Swierczek, A.J. Copik, S.I. Swierczek, R.C. Holz Molecular discrimination of type-I over type-II methionyl aminopeptidases Biochemistry, 44 (2005), pp. 12049-12056

[43] G. Yang, R.B. Kirkpatrick, T. Ho, G.-F. Zhang, P.-H. Liang, K.O. Johanson, D.J. Casper, M.L. Doyle, J.P. Marino, S.K. Thompson, W. Chen, D.G. Tew, T.D. Meek Steady-state kinetic characterization of substrates and metal-ion specificities of the full-length and $\mathrm{N}$-terminally truncated recombinant human methionine aminopeptidases (type 2) Biochemistry, 40 (2001), pp. 10645-10654

[44] Y.-H. Chang, U. Teichert, J.A. Smith Purification and characterization of a methionine aminopeptidase from Saccharomyces cerevisiae J. Biol. Chem., 265 (1990), pp. 19892-19897

[45] I.H. Segel Enzyme Kinetics: Behavior and Analysis of Rapid Equilibrium and Steady-State Enzyme Systems John Wiley, New York (1975)

[46] R. Lumry, E.L. Smith, R.R. Glantz Kinetics of carboxypeptidase action: I. Effect of various extrinsic factors on kinetic parameters J. Am. Chem. Soc., 73 (1951), pp. 4330-4340

[47] S. Kunugi, $\mathrm{H}$. Hirohara, N. Ise pH and temperature dependences of thermolysis catalysis: catalytic role of zinc-coordinated water Eur. J. Biochem., 124 (1982), pp. 157-163

[48] C.-H. Wu, W.-Y. Lin Effects of metal ions on the catalytic and thermodynamic properties of the aminopeptidase isolated from pronase J. Inorg. Biochem., 57 (1995), pp. 79-89

1 Abbreviations used: MetAP, methionine aminopeptidase; EcMetAP-I, type I MetAP from Escherichia coli; SaMetAP-I, type I MetAP from Staphylococcus aureus; TmMetAP-I, type I MetAP from Thermotoga maritime; HsMetAP-I, type I MetAP from Homo sapiens; HsMetAP-II, type II MetAP from Homo sapiens; PfMetAP-II, type II MetAP from Pyrococcus furiosus; HPLC, high-performance liquid chromatography; SDS-PAGE, sodium dodecyl sulfate-polyacrylamide gel electrophoresis; TFA, trifluoroacetic acid; DTNB, 5,5'-dithio-bis(2-nitrobenzoic) acid; I-Met-AMC, I-methionine-7-amido-4-methylcoumarin. 